\title{
HUBUNGAN KONDISI LINGKUNGAN FISIK TERHADAP TINGKAT KEPADATAN LARVA Aedes $s p$ DI SEKOLAH DASAR WILAYAH KECAMATAN KASIHAN, BANTUL, DI YOGYAKARTA
}

\author{
Puji Astuti, Elisabeth Deta Lustiyati \\ Program Studi Kesehatan Masyarakat Universitas Respati Yogyakarta

\begin{abstract}
THE CORRELATION OF PHYSICAL ENVIRONMENT CONDITION TO LEVEL OF Aedes sp LARVAE DENSITY AT AREA OF ELEMENTARY SCHOOLS OF KASIHAN SUBDISTRICT, BANTUL, SPECIAL REGION OF YOGYAKARTA
\end{abstract}

\begin{abstract}
Background: Data from the Health Service of Yogyakarta 2016 show that the highest dengue fever case is in Bantul District is precisely in Kasihan Subdistrict. One of the factors that influence the density of Aedes sp larvae is the physical environment including light intensity, ventilation, drainage, and distance between buildings. The results of larvae surveys show that from 11 containers, four are Aedes sp larvae, so that the Container Index obtained (CI) is $36 \%$ belonging to high density. This study aimed examined the relationship between physical environment condition and Aedes sp larvae density level.

Methods: This study was an observational analytic study with cross sectional design. The numbers of samples in this study were 30 elementary schools. The sampling technique employed total sampling. Data analysis were using univariate dan bivariate analysis by using Spearman test.

Results: Percentage of school are qualified in the physical environment of light (13.3\%), ventilation (16,7\%), drainage (56.7\%), the distance between buildings (60.0\%). Larvae Aedes sp density were House Index $(H I)=90 \%$, mean of Container Index $(C I) 25,23 \%$, and Breteau Index $(B I)=33$ that was Density Figure level 9 (high density). The variables significantly associated with the larvae Aedes sp density were light density $(p=0,029)$, the installation of wire gauze $(p=0,004)$, and drain water reservoir/drainage $(p=0,011)$

Conclusions: There is relationship between the light intensity, wire gauze, and drainage with the Aedes sp larvae density.

Keywords: Aedes sp, larvae density, physical environment condition, school
\end{abstract}

\begin{abstract}
ABSTRAK
Latar belakang: Data Dinas Kesehatan DIY 2016 menunjukan bahwa kasus DBD tertinggi berada di Kecamatan Kasihan, Kabupaten Bantul. Salah satu faktor yang mempengaruhi kepadatan larva Aedes sp adalah lingkungan fisik meliputi intensitas cahaya, ventilasi, drainage, dan jarak antar bangunan. Hasil survey larva diperoleh hasil dari 11 kontainer, empat positif larva Aedes sp sehingga diperoleh Container Index (CI) 36\% tergolong kepadatan tinggi. Penelitian ini bertujuan untuk mengetahui hubungan antara kondisi lingkungan fisik dengan tingkat kepadatan larva Aedes sp.

Metode: Jenis penelitian ini merupakan observasional analitik dengan rancangan cross sectional. Jumlah sampel dalam penelitian ini sebanyak 30 sekolah dasar. Teknik sampling menggunakan total sampling dengan analisis data menggunakan uji korelatif Spearman $(\alpha=0,05)$.

Hasil: Kondisi lingkungan fisik sekolah yang telah memenuhi persyaran pada variabel intensitas cahaya $(13,3 \%)$, ventilasi $(16.7 \%)$, drainage $(56,7 \%)$, jarak antar bangunan memenuhi syarat $(60,0 \%)$. Hasil perhitungan kepadatan larva Aedes sp di sekolah dasar wilayah Kecamatan Kasihan diperoleh hasil House Index $(\mathrm{HI})=90 \%$, Container Index $(\mathrm{CI})$ rata-rata 25,23\%, dan Breteau Index $(\mathrm{BI})=333$ dengan DF $=9$ tergolong kategori kepadatan tinggi.Hasil penelitian menunjukkan terdapat tiga variabel yang berhubungan dengan kepadatan larva Aedes sp yaitu intensitas cahaya $(p=0,029)$, ventilasi $(p=0,004)$, dan drainase $(\mathrm{p}=0,011)$.

Kesimpulan: Ada hubungan antara intensitas cahaya, ventilasi dan drainase dengan kepadatan larva Aedes sp.

Kata Kunci: Kepadatan larva Aedes sp, lingkungan fisik, sekolah dasar
\end{abstract}

Alamat Koresponding: Elisabeth Deta Lustiyati, Program Studi Kesehatan Masyarakat Universitas Respati Yogyakarta, Jalan Raya Tajem Km.1,5 Maguwoharjo, Sleman, DIY, Email: elisabethdeta@ respati.ac.id 


\section{PENDAHULUAN}

Jumlah kasus DBD di Indonesia mengalami peningkatan pada tahun 2015 yaitu sebanyak 129.650 kasus. Penderita DBD di Indonesia pada bulan Januari-Februari 2016 sebanyak 13.219 penderita, dari jumlah penderita tersebut diketahui bahwa $42,72 \%$ adalah penderita pada golongan usia 5-14 tahun. Salah satu provinsi yang belum mencapai target Renstra untuk angka kesakitan DBD adalah provinsi Daerah Istimewa Yogyakarta ${ }^{1}$ Data Dinkes Provinsi DIY (2014) menunjukan bahwa penderita DBD terbanyak adalah golongan usia 5-14 tahun sebanyak 355 penderita. Sebaran kasus DBD di DIY tersebar di lima kabupaten, kasus tertinggi berada di Kabupaten Bantul yaitu sebanyak 622 kasus $^{2}$ Kasus DBD paling tinggi terjadi di Kecamatan Kasihan. Berdasarkan data terbaru Dinkes Kab. Bantul (2016) pada bulan Januari - September tahun 2016 kasus DBD di Kecamatan Kasihan mencapai 291 kasus dengan proporsi penderita terbanyak adalah golongan usia 513 tahun sebanyak 82 orang. $^{3}$

Faktor lingkungan fisik yang dapat berpengaruh terhadap tingkat kepadatan larva Aedes sp yaitu intensitas cahaya, ventilasi, drainase, dan jarak antar bangunan. Pencahayaan berhubungan dengan kepadatan larva Aedes sp. Intensitas cahaya merupakan faktor terbesar yang mempengaruhi kehidupan nyamuk Aedes sp. Cahaya yang rendah dan kelembaban tinggi merupakan kondisi yang baik bagi kehidupan nyamuk. ${ }^{4}$

Kawat kasa adalah salah satu alat pelindung yang terbuat dari kawat dan biasanya dipasang di lubang ventilasi, Hasil penelitian menunjukkan bahwa pada kelompok kasus terdapat 40 (76,9\%) rumah yang ventilasinya tidak berkasa sehingga berisiko tinggi terhadap kejadian DBD dan 12 $(23,1 \%)$ rumah yang ventilasinya berkasa sehingga berisiko rendah terhadap kejadian DBD. Pada kelompok kontrol terdapat 14 $(26,9 \%)$ rumah yang ventilasinya tidak berkasa dan $38 \quad(73,1 \%)$ rumah yang ventilasinya berkasa. ${ }^{5}$

Drainage merupakan salah satu breeding place nyamuk Aedes sp karena nyamuk dewasa meletakan telurnya pada dinding sedikit diatas genangan air dan berkembangbiak menjadi larva. Sistem drainage yang belum berfungsi dengan baik akan mengakibatkan terjadinya genangan air dan akan menjadi tempat perkembangbiakan nyamuk Aedes aegypti. ${ }^{6}$

Jarak antar rumah atau bangunan yang terlalu dekat merupakan faktor risiko DBD. Tingginya indeks jentik Aedes $s p$ di sekolah dasar di Kota Semarang tidak hanya mengancam warga sekolah saja, tetapi juga mengancam penduduk yang tinggal di sekitar lingkungan sekolah (7) . Hal tersebut dikarenakan sebagian besar sekolah terletak di tengah-tengah pemukiman penduduk dan nyamuk Aedes $s p$ betina mempunyai kemampuan terbang rata-rata 40-100 m sehingga memungkinkan nyamuk Aedes sp masuk ke pemukiman penduduk sekitar sekolah

Data sebelumnya menyatakan bahwa proporsi penderita DBD terbanyak berada pada golongan anak-anak dengan rentang usia 5-14 tahun. Anak usia 5-14 tahun merupakan golongan anak usia sekolah dasar, yang mana anak usia sekolah dasar mulai melakukan kegiatannya di sekolah sejak pukul 07:00 WIB, hal tersebut bertepatan dengan beredarnya nyamuk Aedes aegypti untuk menginfeksi manusia dengan gigitannya yaitu pukul 09:00 - 10:00 WIB dan 16:00 - 17:00 WIB. $^{7}$ Apabila kualitas kebersihan lingkungan sekolah buruk, maka hal tersebut berpotensi sebagai tempat perkembangbiakan larva Aedes sp. Semakin banyaknya kondisi lingkungan fisik di sekolah yang berpotensial sebagai tempat perkembangbiakan larva Aedes sp akan menambah jumlah populasi nyamuk Aedes aegypti apabila tidak dilakukan kegiatan pembersihan. Adanya nyamuk Aedes 
aegypti di wilayah sekolah dikhawatirkan akan menjadi vektor penular penyakit DBD. ${ }^{8}$

Dalam mewujudkan lingkungan sekolah yang sehat serta bebas larva maka perlu dilakukan survei larva secara berkala. Survei larva dilakukan dengan cara melakukan pengamatan terhadap semua media perairan yang potensial sebagai tempat perkembangbiakan nyamuk. Hasil survei larva Aedes sp dicatat dan dilakukan analisis menggunakan house index (HI), container index (CI), dan breteau index (BI) untuk mengetahui tingkat kepadatan larva. ${ }^{9}$

Berdasarkan hasil observasi pada studi pendahuluan observasi mengenai kondisi lingkungan sekolah yaitu setiap ruang kelas memiliki jendela, namun tidak dibuka serta tirai tertutup sehingga kodisi ruangan gelap. Ventilasi di setiap ruangan tidak dipasang kasa nyamuk. Hasil pengukuran jarak antar bangunan didapatkan 2-3 m sehingga tidak memenuhi syarat karena $\leq 5 \mathrm{~m}$. Kondisi drainage yang berada di lingkungan sekolah tidak memenuhi syarat karena ada saluran air, tidak mengalir lancar dan terdapat genangan air. Hal tersebut berpotensi sebagai perkembangbiakan larva Aedes sp. Hasil survey larva diperoleh hasil dari 11 kontainer, empat positif larva Aedes $s p$ sehingga diperoleh Container Index (CI) 36\% tergolong dalam kategori kepadatan tinggi.

Berdasarkan uraian latar belakang maka penulis tertarik untuk melakukan penelitian tentang hubungan antara kondisi lingkungan fisik dengan tingkat kepadatan larva Aedes $s p$ di sekolah dasar wilayah Kecamatan Kasihan, Kabupaten Bantul.

\section{METODE}

Jenis penelitian ini adalah observasional analitik menggunakan pendekatan cross sectional. Pengambilan data dalam penelitian ini telah dilaksanakan pada bulan Januari - Maret 2017 di 30 sekolah dasar yang berada di wilayah Kecamatan
Kasihan, Kabupaten Bantul, Provinsi Daerah Istimewa Yogyakarta.

Populasi penelitian ini adalah seluruh sekolah dasar di wilayah Kecamatan Kasihan yaitu sebanyak 34 sekolah dasar berdasarkan data Dinas Pendidikan Dasar Kabupaten Bantul Tahun 2015. Sampel dalam penelitian ini adalah sekolah dasar yang bersedia menjadi tempat penelitian di wilayah Kecamatan Kasihan yaitu 30 sekolah dasar. Metode pengambilan sampel dalam penelitian ini adalah total sampling.

Pengambilan sampel larva di dilakukan di dalam dan luar kelas dengan metode single larva, selanjutnya perhitungan kepadatan larva menggunakan ukuran CI, HI, dan BI. Pemeriksaan dilakukan di 30 sekolah dasar dengan jumlah titik pengambilan container potensial larva yang ditemukan sejumlah 412 titik. Pengukuran kondisi lingkungan fisik intensitas cahaya dilakukan di setiap ruang letak ditemukan kontainer dengan menggunakan alat luxmeter, selain itu penilaian kondisi ventilasi juga dilakukan di dalam ruangan dengan jumlah total titik pengukuran untuk intensitas cahaya dan ventilasi ada 258 titik. Selanjutnya pada penilaian drainage dan jarak antar bangunan dilakukan dengan metode observasi.

Pada analisis data sebagai parameter kepadatan larva menggunakan nilai CI yang dapat mewakili setiap sekolah dasar, yaitu nilai persentase wadah (container) positif larva dibandingkan dengan jumlah wadah yang diperiksa di suatu tempat. Parameter terpenuhinya persyaratan dari ventilasi menggunakan skoring, yaitu skor 1 (jika seluruh ventilasi tidak terpasang kawat kasa), skor 2 (jika hanya sebagian ventilasi yang terpasang kawat kasa), skor 3 (jika seluruh ventilasi terpasang kawat kasa). Selain ventilasi, skoring juga dilakukan pada hasil observasi drainase yang ada di lingkungan SD, yaitu skor 1 (jika tidak ada saluran air dan terdapat genangan air), skor 2 (jika ada saluran air, tetapi air tidak mengalir 218ariab dan terdapat genangan air), skor 3 (jika ada 
saluran air dan air mengalir 219ariab, akan tetapi masih terdapat genangan air), skor 4 (jika ada saluran air, air mengalir 219 ariab dan tidak ada genangan air). Penilaian untuk jarak antar bangunan dengan melakukan pengukuran jarak pada keempat sisi bangunan sekolah dengan bangunan di sebelahnya. Penilaian skor 1 (jika tidak ada sisi dari bangunan sekolah yang memiliki jarak $\geq 5$ meter dengan bangunan di sebelahnya) selanjutnya skor akan semakin tinggi menyesuaikan dengan jumlah sisi dari bangunan sekolah yang memiliki jarak antar bangunan sesuai 219ariable yaitu dengan skor tertinggi, skor 5 (jika keempat sisi dari bangunan sekolah memiliki jarak $\geq 5$ meter dengan bangunan di sebelahnya.

Teknik analisis data yang dilakukan pada penelitian ini adalah analisis univariat dan bivariat. Analisis univariat bertujuan untuk menjelaskan atau mendeskripsikan karakteristik setiap variabel penelitian. Pada

Tabel 1.

Gambaran Kondisi Lingkungan Fisik yang Berhubungan dengan Kepadatan Vektor di Sekolah Dasar Kecamatan Kasihan, Bantul, DIY

\begin{tabular}{llccccc}
\hline No & Nama Sekolah Dasar (SD) & $\begin{array}{c}\text { Nilai } \\
\boldsymbol{C I}\end{array}$ & $\begin{array}{c}\text { Intensitas } \\
\text { Cahaya }\end{array}$ & Ventilasi & Drainase & $\begin{array}{c}\text { Jarak } \\
\text { Antar } \\
\text { Bangunan }\end{array}$ \\
\hline 1 & SDN 2Kadipiro & 28 & 5 & 1 & 2 & 1 \\
2 & SDN 3 Kadipiro & 16 & 24 & 3 & 4 & 1 \\
3 & SDNRejodadi & 0 & 150 & 3 & 4 & 3 \\
4 & SD Muh Ambarbinangun & 13 & 18 & 1 & 4 & 5 \\
5 & SD Kanisius Jomegatan & 44 & 55 & 1 & 2 & 4 \\
6 & SDN2Padokan & 18 & 17 & 2 & 2 & 1 \\
7 & SDNNirmala & 0 & 114 & 2 & 4 & 3 \\
8 & SDN1Padokan & 19 & 114 & 2 & 2 & 2 \\
9 & SD Muh Insan Kreatif & 20 & 35 & 1 & 4 & 5 \\
10 & Kembaran & 46 & 18 & 1 & 2 & 4 \\
11 & SD Muh Senggotan & 46 & 22 & 1 & 4 & 3 \\
12 & SD Muhisius Kembaran & 29 & 7 & 1 & 2 & 4 \\
13 & SDN Kasihan & 36 & 7 & 1 & 4 & 2 \\
14 & SDN Sonosewu & 19 & 21 & 1 & 4 & 2 \\
15 & SDN1 Kadipiro & 27 & 42 & 2 & 2 & 2 \\
16 & SDN Kalangan & 13 & 20 & 1 & 4 & 5
\end{tabular}

penelitian ini analisis univariat meliputi analisis variabel kondisi lingkungan fisik pada intensitas cahaya, ventilasi, drainase, dan jarak antar bangunan, serta kepadatan larva Aedes $s p$ berdasarkan $H I, C I, B I$, dan $D F$ menggunakan nilai frekuensi dan proporsi. Analisis data yang dipergunakan dalam data numerik penelitian ini ada uji hipotesis korelasi Pearson apabila syarat normalitas terpenuhi atau uji Spearman apabila variabel berdistribusi tidak normal.

\section{HASIL \\ Gambaran Lingkungan Fisik}

Kondisi lingkungan fisik meliputi : intensitas cahaya, ventilasi, drainase, dan jarak antar bangunan di sekolah dasar diduga berhubungan dengan kepadatan vektor di setiap sekolah (nilai CI) seperti yang disajikan pada Tabel 1 :

$$
\text { ketiap variabel penelitian. Pada }
$$




\begin{tabular}{llccccc}
\hline No & Nama Sekolah Dasar (SD) & $\begin{array}{c}\text { Nilai } \\
\boldsymbol{C I}\end{array}$ & $\begin{array}{c}\text { Intensitas } \\
\text { Cahaya }\end{array}$ & Ventilasi & Drainase & $\begin{array}{c}\text { Jarak } \\
\text { Antar } \\
\text { Bangunan }\end{array}$ \\
\hline 17 & SDN Sembungan & 0 & 109 & 3 & 4 & 2 \\
18 & SD Mutiara Persada & 17 & 37 & 3 & 4 & 5 \\
19 & SDN Sambikerep & 29 & 24 & 1 & 2 & 5 \\
20 & SDN Bangunjiwo & 20 & 9 & 1 & 2 & 4 \\
21 & SDN Bibis & 29 & 21 & 1 & 2 & 2 \\
22 & SDN Kalipucang & 27 & 21 & 2 & 4 & 2 \\
23 & SDN Banyuripan & 54 & 18 & 1 & 1 & 5 \\
24 & SDN Kasongan & 50 & 11 & 1 & 4 & 2 \\
25 & SDN Donotirto & 18 & 20 & 1 & 4 & 5 \\
26 & SDN Winongo & 20 & 12 & 1 & 4 & 5 \\
27 & SD Muh Tamantirto & 39 & 21 & 1 & 2 & 2 \\
28 & SDN Karangjati & 18 & 35 & 2 & 4 & 5 \\
29 & SDN Sribitan & 20 & 18 & 1 & 2 & 3 \\
30 & SDN Tlogo & 42 & 20 & 3 & 4 & 2 \\
\hline
\end{tabular}

Penilaian terpenuhinya pesyaratan lingkungan fisik yaitu intensitas cahaya berdasarkan hasil rata-rata pengukuran intensitas cahaya di setiap ruangan sekolah tempat diperoleh kontainer larva. Intensitas cahaya termasuk Memenuhi Syarat apabila cahaya dalam ruangan terukur lebih dari 60 lux. Parameter ventilasi di sekolah dasar dinilai Memenuhi Syarat hanya jika seluruh ventilasi di dalam ruang terpasang kawat kasa. Penilaian variabel drainage Memenuhi Syarat hanya jika ada saluran air dan air mengalir lancar, serta tidak terlihat genangan air. Jarak antar bangunan di lokasi penelitian dinilai Memenuhi Syarat hanya jika minimal 2 sisi bangunan memiliki jarak $\geq 5$ meter dengan bangunan di sebelahnya. (Tabel 2)

Tabel 2.

\section{Pemenuhan Persyaratan Kondisi Lingkungan Fisik di Sekolah Dasar Kecamatan Kasihan, Bantul, DIY}

\begin{tabular}{ccccc}
\hline \multirow{2}{*}{ Kategori } & \multicolumn{4}{c}{ Variabel } \\
\cline { 2 - 5 } & $\begin{array}{c}\text { Intensitas } \\
\text { Cahaya }\end{array}$ & Ventilasi & Drainase & $\begin{array}{c}\text { Jarak Antar } \\
\text { Bangunan }\end{array}$ \\
\hline Memenuhi syarat & $4(13 \%)$ & $5(17 \%)$ & $17(57 \%)$ & $18(60 \%)$ \\
Tidak memenuhi syarat & $26(87 \%)$ & $25(83 \%)$ & $13(43 \%)$ & $12(40 \%)$ \\
Total & $\mathbf{3 0 ( 1 0 0 \% )}$ & $\mathbf{3 0}(\mathbf{1 0 0 \%})$ & $\mathbf{3 0}(\mathbf{1 0 0 \%})$ & $\mathbf{3 0}(\mathbf{1 0 0 \%})$ \\
\hline
\end{tabular}

Hasil observasi kepadatan larva Aedes $s p$ di 30 sekolah dasar wilayah Kecamatan Kasihan Kabupaten Bantul, diperoleh 27 sekolah dasar positif larva Aedes sp dan 3 sekolah dasar negatif larva Aedes sp. Hasil perhitungan House Index $(H I)=90 \%$, Container Index (CI) menunjukan bahwa dari 30 sekolah dasar yang diteliti $14(46,7 \%)$ sekolah dasar memiliki $C I$ dengan risiko tinggi, $13(43,3 \%)$ risiko sedang, $3(10 \%)$ risiko rendah, dan Breteau Index $(B I)=333$. Berdasarkan nilai HI, CI, dan BI maka diperoleh nilai Density figure $(D F)=9$ artinya kepadatan larva Aedes $s p$ di sekolah dasar wilayah Kecamatan Kasihan, Kabupaten Bantul tergolong tinggi. 


\section{Hubungan Antar Variabel Penelitian}

Uji normalitas (Shapiro Wilk) pada variabel kondisi fisik lingkungan mempunyai nilai $\mathrm{p}<0,05$, oleh karena itu kelompok data memiliki distribusi tidak normal (Tabel 3).

Tabel 3.

Uji Normalitas Kondisi Lingkungan Fisik

\begin{tabular}{lcc}
\hline \multicolumn{1}{c}{ Lingkungan Fisik } & Nilai Sig. & Keterangan \\
\hline Intensitas cahaya & 0,000 & distribusi tidak normal \\
Ventilasi & 0,000 & distribusi tidak normal \\
Drainase & 0,000 & distribusi tidak normal \\
Jarak Antar Bangunan & 0,001 & distribusi tidak normal \\
\hline
\end{tabular}

Hasil analisis bivariat hubungan antara kepadatan vektor (nilai CI) menggunakan uji kondisi fisik lingkungan (intensitas cahaya, korelasi Spearman, sebagai berikut: ventilasi, drainase, jarak bangunan) dengan

Tabel 4.

Hubungan Kondisi Lingkungan Fisik dengan Kepadatan Larva Ae.aegypti di Sekolah Dasar Kecamatan Kasihan, Bantul, DIY

\begin{tabular}{lcl}
\hline Lingkungan Fisik & $\begin{array}{c}\text { Kepadatan Vektor } \\
\text { (Container Index, CI) } \mathbf{n}=\mathbf{3 0}\end{array}$ & \multicolumn{1}{c}{ Keterangan } \\
\hline Intensitas cahaya & $\mathrm{r}=-0,399$ & signifikan, kekuatan \\
& $\mathrm{p}=0,029$ & korelasi lemah \\
Ventilasi & $\mathrm{r}=-0,505$ & signifikan, kekuatan \\
& $\mathrm{p}=0,004$ & korelasi sedang \\
Drainase & $\mathrm{r}=-0,458$ & signifikan, kekuatan \\
& $\mathrm{p}=0,011$ & korelasi sedang \\
Jarak antar & $\mathrm{r}=-0,083$ & tidak signifikan, \\
bangunan & $\mathrm{p}=0,662$ & $\begin{array}{l}\text { kekuatan korelasi } \\
\text { sangat lemah }\end{array}$ \\
\hline
\end{tabular}

Hasil uji korelasi Spearman diperoleh bahwa antara kondisi fisik lingkungan yaitu intensitas cahaya, ventilasi, dan drainase memiliki hubungan yang signifikan dengan kepadatan vektor $(\mathrm{p}<0,05)$. Hal berbeda diperoleh dari uji korelatif Spearman pada variabel jarak antar bangunan tidak ada hubungan signifikan dengan kepadatan vektor.

Kekuatan hubungan antara kondisi fisik dengan kepadatan vektor berdasarkan nilai korelasi Pearson diperoleh bahwa intensitas cahaya (kekuatan korelasi lemah), ventilasi (kekuatan korelasi sedang), drainase (sedang), dan jarak antar bangunan (sangat lemah)

\section{PEMBAHASAN \\ Intensitas Cahaya}

Kepadatan larva Aedes sp di sekolah dasar wilayah Kecamatan Kasihan diperoleh hasil House Index $(H I)=90 \%$, Container Index (CI) rata-rata $25,23 \%$, dan Breteau Index (BI) 
= 333 dengan $D F=9$ maka tergolong dalam kategori kepadatan tinggi. Tingginya indeks jentik Aedes sp di sekolah dasar tidak hanya mengancam warga sekolah saja, tetapi dapat mengancam penduduk yang tinggal di sekitar lingkungan sekolah. ${ }^{10}$

Berdasarkan hasil observasi intensitas cahaya tidak memenuhi syarat banyak ditemukan di ruang kamar mandi, hal tersebut berkaitan dengan letak kamar mandi. Letak kamar mandi di sebagian besar sekolah dasar memanjang dengan pintu saling berhadapan, sehingga letak kamar mandi yang paling pojok tidak mendapatkan cahaya yang cukup. Penerangan lampu di setiap kamar mandi juga tidak dinyalakan setiap saat sehingga ruangan gelap. Setiap kamar mandi memiliki kontainer atau tempat penampungan air, dengan keadaan pencahayaan yang sangat kurang seperti yang dipaparkan diatas, hal tersebut berpotensi sebagai tempat perkembangbiakan larva Aedes sp.

Intensitas pencahayaan yang masuk kedalam kamar mandi masih tergolong rendah karena ditemukan sebagian besar kamar mandi dalam kondisi gelap, hal tersebut sangat berpengaruh dalam perkembangbiakan nyamuk karena kebiasaan nyamuk meletakkan telur-telurnya di tempat yang sedikit cahaya dan lembab untuk melanjutkan proses perkembangbiakan selanjutnya. ${ }^{11}$

Hasil uji statistik diperoleh ada hubungan bermakna $(\mathrm{p}=0,029)$ antara intensitas cahaya dengan CI. Hal ini sejalan dengan penelitian yang lain, yaitu kontainer yang paling banyak positif jentik terdapat pada kondisi dengan pencahayaan kurang ( $\leq$ 60 lux $)^{12,13}$ Intensitas cahaya merupakan faktor terbesar yang mempengaruhi aktifitas terbang nyamuk. Nyamuk terbang pada intensitas cahaya dibawah 60 lux. Cahaya yang rendah dan kelembaban tinggi merupakan kondisi yang baik bagi nyamuk. ${ }^{4}$

Korelasi negatif $(r=-0,339)$ hasil penelitian ini menandai adanya hubungan berbanding terbalik antara intensitas cahaya dengan CI. Apabila intensitas cahaya yang dipancarkan semakin tinggi atau besar ke permukaan maka suhu lingkungan akan semakin tinggi. Sedangkan semakin tinggi intensitas cahaya yang dipancarkan ke permukaan maka kelembaban di suatu lingkungan akan menjadi lebih rendah. ${ }^{14}$ Nyamuk Aedes $s p$ dapat bertelur dan berkembang biak pada intensitas cahaya yang rendah hingga tinggi, pada tempat-tempat gelap maupun terang. ${ }^{15}$

\section{Ventilasi}

Suatu bangunan atau rumah dengan kondisi ventilasi tidak terpasang kawat kasa atau strimin akan memudahkan nyamuk untuk masuk ke dalam bangunan untuk menggigit manusia, beristirahat, dan mendapatkan tempat untuk berkembangbiak. ${ }^{16}$

Berdasarkan uji statistik diperoleh ada hubungan bermakna antara ventilasi yang dilengkapi kawat kasa dengan $\mathrm{CI}(\mathrm{p}=0,004)$. Pemakaian kawat kasa pada ventilasi merupakan salah satu upaya untuk mencegah penyakit demam berdarah dengue. Pemakaian kawat kasa pada setiap lubang ventilasi disetiap ruangan bertujuan agar nyamuk tidak masuk ke dalam rumah dan menggigit manusia. Ventilasi dikatakan memenuhi syarat kesehatan bila pada lubang ventilasi terpasang jaring-jaring atau kawat kasa. ${ }^{5}$ Semakin banyak bagian ventilasi terpasang kawat kasa maka semakin kecil pula kepadatan vektor di dalam ruang ditandai dengan nilai korelasi negatif $(r=-0,505)$ dari penelitian ini. Berdasarkan penelitian sebelumnya, rumah yang tidak memiliki kawat kasa berisiko terjadi penyakit DBD. ${ }^{17,18}$ Ventilasi yang dilengkapi dengan kawat kasa akan memperkecil kontak nyamuk dengan manusia di dalam ruangan karena nyamuk dari luar ruangan tidak dapat masuk ke dalam ruangan.

\section{Drainase}

Drainase yang terdapat di setiap sekolah dasar keadaan alirannya lancar 
sehingga tidak menimbulkan genangan air, serta kondisi drainage di setiap sekolah dasar secara langsung terpapar sinar matahari. Kondisi drainage tersebut tidak disukai oleh larva Aedes sp, hal ini berkaitan dengan tempat perindukan larva Aedes sp yang kurang menyukai tempat perindukan di luar rumah karena lebih sering terkena cahaya matahari secara langsung. ${ }^{19}$ Hasil uji statistik korelasi Spearman diperoleh ada hubungan bermakna $(p=0,011)$ antara nilai kelancaran drainase dengan CI. Drainage atau saluran air sebagai salah satu tempat yang berpotensi sebagai tempat perkembangbiakan larva Aedes sp. Hasil penelitian ini didukung oleh penelitian Nugrahaningsih bawah ada hubungan antara keberadaan saluran air hujan dengan keberadaan nyamuk penular DBD. ${ }^{20}$ Drainase yang tidak berfungsi dengan baik akan menimbulkan genangan air yang dapat digunakan sebagai tempat perkembangbiakan larva Aedes sp. Waktu peralihan dari musim kemarau ke penghujan merupakan titik rawan kejadian DBD, terlebih jika saluran air hujan tidak mengalir dengan lancar. Oleh karena itu, gotong royong dalam upaya membersihkan got dan mengembalikan fungsi drainase wajib dilakukan sehingga kejadian luar biasa DBD dapat dicegah.

Korelasi bernilai negatif sebesar $\mathrm{r}=$ 0,458 hasil penelitian pada hubungan antara kelancaran drainase dengan kepadatan vector (nilai CI) menunjukkan hubungan tersebut berbanding terbalik. Sistem drainase yang berfungsi dengan baik akan mencegah perkembangbiakan vektor Aedes $s p{ }^{6}$

\section{Jarak Antar Bangunan}

Lokasi sekolah dasar di Kecamatan Kasihan dengan jarak antar bangunan memenuhi syarat sebagian besar berada di wilayah pedesaan, sehingga memiliki jarak yang jauh dengan pemukiman atau perumahan warga karena terpisah oleh lahan kosong atau pekarangan. Hasil uji statistik diperoleh tidak ada hubungan bermakna $(p=0,662)$ antara jarak antar bangunan dengan kepadatan vektor. Hal tersebut dimungkinkan karena sisi bangunan sekolah yang berjarak 5 meter dengan bangunan di sebelahnya diisi oleh vegetasi untuk perindukan vektor atau terdapat genangan air di luar sisi bangunan sekolah untuk perkembangbiakan vektor. Spesies ekologi untuk Ae. aegypti adalah nyamuk anthropohilik yang memiliki kemampuan beradapatasi yang tinggi pada perubahan lingkungan anthropogenic ${ }^{21}$ dan sebagian ditemukan di dalam ruban area perkotaan (urban) dan semi perkotaan (sub urban). Sebagian wilayah Kecamatan Kasihan, Bantul adalah wilayah pedesaan dan merupakan kawasan penyangga pengembangan kota Yogyakarta ke arah Selatan. Oleh karena itu, hingga saat ini perumahan di sebagian wilayah Kecamatan Kasihan telah berkembang dengan pesat. Selain daerah perkotaan, daerah hijau (green area) jugaa dianggap penting dipertimbangkan dalam pelaksanaan surveillance untuk sasaran strategi pengendalian Ae. aegypti. ${ }^{22}$

Daerah perkampungan memiliki tata letak yang tidak beraturan. Hal ini disebabkan daerah perkampungan proses keberadaan dan perkembangannya tidak terencana, baik itu jaringan jalan atau tata letak bangunan permukiman itu sendiri. Salah satu dampak dari keberadaan dan perkembangan yang tidak terencana di daerah perkampungan yaitu tata letak bangunan antara bangunan satu dengan yang lainnya terpisah oleh lahan kosong atau pekarangan, dimana pada lahan kosong atau pekarangan tersebut terdapat tumbuhan yang merupakan tempat untuk berkembangbiak nyamuk pembawa vektor penyakit Demam Berdarah Dengue (DBD), terutama jenis Aedes albopictus yang memang merupakan nyamuk yang hidup di luar rumah, pada semak-semak belukar, atau di pohon-pohon dan tanaman. ${ }^{23}$ DBD dapat dicegah atau dikurangi perkembangannya, dengan cara menciptakan lingkungan yang baik sehingga 
tidak berpotensi sebagai tempat perkembangbiakan larva Aedes aegypti dan Aedes albopictus.

\section{KESIMPULAN DAN SARAN}

Kondisi lingkungan yang berhubungan dengan kepadatan larva Aedes sp di sekolah dasar wilayah Kecamatan Kasihan, Bantul, D.I Yogyakarta adalah intensitas cahaya, ventilasi dan saluran air hujan, sedangkan pada variabel jarak antar bangunan tidak memiliki hubungan signifikan dengan kepadatan larva Aedes sp. Semua variabel penelitian kondisi lingkungan fisik memiliki

\section{DAFTAR PUSTAKA}

1. RI KK. Profil Kesehatan Indonesia Jakarta: Kementerian Kesehatan RI; 2015.

2. DIY DKP. Profil Dinas Kesehatan Provinsi DIY Yogyakarta: Dinkes Provinsi DIY; 2014.

3. Bantul DKK. Data Penyakit DBD Dinas Kesehatan Kabupaten Bantul Tahun 2016 Bantul: Dinkes Bantul; 2016.

4. Astuti, Nurdiana, Salawati. Kejadian Demam Berdarah Dengue Berdasarkan Faktor Lingkungan dan Praktik Pemberantasan Sarang Nyamuk. Jurnal Kesehatan Masyarakat Indonesia. 2010; 6(2).

5. Maria, Ishak, Selomo. Faktor Risiko Kejadian Demam Berdarah Dengue (DBD) di Kota Makasar Tahun 2013. Jurnal Kesehatan Lingkungan. 2013; 12(6).

6. Sofia, Suhartono, Wahyuningsih. Hubungan Kondisi Lingkungan Rumah dan Perilaku Keluarga dengan Kejadian Demam Berdarah Dengue di Kabupaten Aceh Besar Tahun 2014. Jurnal Kesehatan Lingkungan. 2014; 13(1).

7. Ginanjar, Martini, Sari. Hubungan Kepadatan Jentik Aedes sp dan Praktik PSN dengan Kejadian DBD di Sekolah Tingkat Dasar di Kota Semarang. Jurnal Kesehatan Masyarakat. 2014; 13(1).

8. Kementerian Kesehatan RI Direktorat Jenderal Pengendalian Penyakit dan Penyehatan Lingkungan. Pedoman Pengendalian Demam Berdarah Dengue di korelasi negatif dengan kepadatan larva Aedes $s p$.

Bagi kepala sekolah di setiap sekolah khususnya untuk sekolah dasar yang memiliki kepadatan larva Aedes sp tinggi agar menciptakan kondisi lingkungan sekolah yang sehat dengan cara meningkatkan penerangan atau pencahayaan pada setiap ruangan terutama ruangan yang mempunyai kontainer seperti kamar mandi agar tidak menjadi tempat perkembangbiakan larva Aedes sp, melakukan pemeriksaan larva Aedes $s p$ secara berkala yaitu setiap enam bulan di lingkungan sekolah, serta mengembalikan fungsi drainase di lingkungan sekolah khususnya pada peralihan musim kemarau ke penghujan.

Indonesia Jakarta: Kementerian Kesehatan RI; 2015.

9. Soedarto. Demam Berdarah Dengue Haemorhagic Fever Jakarta: Sagung Seto; 2012.

10. Ginanjar, Martini, Sari. Hubungan Kepadatan Jentik Aedes sp dan Praktik PSN dengan Kejadian DBD di Sekolah Tingkat Dasar di Kota Semarang. Jurnal Kesehatan Masyarakat. ; 1(2).

11. Herlyana, Dhita, Sunarsih, Elvi. Hubungan Sanitasi Perumahan Dengan Keberadaan Jentik Aedes sp di Wilayah Kerja Puskesmas Kutaraya Kayu Agung. Jurnal Ilmu Kesehatan Masyarakat. 2015; 6(3).

12. Pohan, Nidar.,Wati, Nur Alvira.,Nurhadi,Muhammad. Gambaran Kepadatan dan Tempat Potensial Perkembangbiakan Jentik Aedes sp di Tempat-Tempat Umum Wilayah Kerja Puskesmas Umbulharjo I Kota Yogyakarta. Jurnal Formil Kesmas Respati. 2016; 1(2).

13. Kusrianto. Kajian Kepadatan dan Karakteristik Habitat Larva Aedes aegypti di Kabupaten Sumedang Jawa Barat. Institut Pertanian Bogor; 2017.

14. B W, Sayono, U N. Pengaruh Penggunaan Cahaya Buatan Terus Menerus Terhadap Perilaku Aedes aegypti Menghisap Darah. Jurnal Kesehatan Masyarakat Indonesia. 2011; 7(1).

15. Fatmawati, $\mathrm{T} N, \mathrm{~B}$ P. Distribusi dan Kelimpahan Populasi Aedes sp di 
Kelurahan Sukorejo Gunungpati Semarang Berdasarkan Peletakan Ovitrap. Unnes Journal of Life Science. 2014; 2(1).

16. Amrieda, Elvin, Tirtasari, Asfian, Pitrah, Ainurafiq. Faktor-faktor yang Berhubungan dengan Kepadatan Jentik Aedes sp di Kecamatan Wundulako Kabupaten Kolaka Tahun 2016. Jurnal Ilmiah Mahasiswa Kesehatan Masyarakat. ; 1(3).

17. Novrita B, Mutahar R, Purnamasari I. Analisis Fakttor Risiko Kejadian Demam Berdarah Dengue di Wilayah Kerja Puskesmas Celikah Kabupaten Ogan Komering Ilir. Jurnal Ilmu Kesehatan Masyarakat. 2017 Maret; 8(01).

18. Ardianti W, Lapau B, Dewi O. Determinan Kejadian Demam Berdarah Dengue (DBD) di Wilayah Kerja Puskesmas Harapan Jaya. Jurnal Photon. 2018 Oktober; 9(1).

19. Nadifah, Muhajir, Arisandi, Lobo. Identifikasi Larva Nyamuk Pada Tempat Penampungan Air di Padukuhan Dero Condong Catur Kabupaten Sleman. Jurnal Kesehatan Masyarakat Andalas. ; 1(3).

20. Nugrahaningsih M, Putra AA, Aryanta IWR. Hubungan Faktor Lingkungan dan Perilaku Masyarkat Dengan Keberadaan Jentik Naymuk Penular Demam Berdarah Dengue (DBD) di Wilayah Kerja Puskesmas Kuta Utara. ECOTROPHIC. 2010; 5(2).

21. Wilke AB, Wilk-da-Silva R, Marelli MT. Microgeographic Population Structuring of Aedes aegypti (Diptera:Culicidae). PLOS ONE. 2017 September.

22. M.R.S H, Diaz-Quijano FA, ChiaravallotiNeto F, Menezes FG, Coelho R, Andrarade $\mathrm{PdS}$, et al. Seasonal and spatial distribution of Aedes aegypti and Aedes albopictus in a. Acta Tropica. 2018 September.
23. Sumunar dan Dyah Respati Suryo. Penentuan Tingkat Kerentanan Wilayah Terhadap Perkembangbiakan Nyamuk Aedes aegypti dan Aedes albopictus dengan Penginderaan Jauh dan Sistem Informasi Geografis. In Internasional Seminar on Mosquito Borne Disease Control Trough Ecological Approaches Departement of Parasitology; 2007; Yogyakarta.

24. Najmah. Epidemiologi Penyakit Menular Jakarta: Trans Info Media; 2016.

25. Awida R. Hubungan Kondisi Fisik Rumah dan Lingkungan Sekitar Rumah dengan Kejadian Malaria di Desa Ketosari Kecamatan Bener Kabupaten Purworejo. Universitas Sumatera Utara; 2008.

26. Fathi, Keman, Wahyuni. Peran Faktor Lingkungan dan Perilaku Terhadap Penularan Demam Berdarah Dengue di Kota Mataram. Jurnal Kesehatan Lingkungan. 2011; 2(1).

27. Suyasa, IN Gede, Putra, Aryanta, IW Redi. Hubungan Faktor Lingkungan dan Perilaku Masyarakat dengan Keberadaan Vektor Demam Berdasarh Dengue (DBD) di Wilayah Kerja Puskesmas I Denpasar Selatan. Jurnal Kesehatan Lingkungan. 2012; 3(1).

28. Badrah, Sitti, dan Hidayah. Hubungan Antara Tempat Perindukan Nyamuk Aedes aegypti dengan Kasus Demam Berdarah Dengue di Kelurahan Penajam Kecamatan Penajam Kabupaten Penajam Paser Utara. J Trop Pharm Chem. 2011; 1(2).

29. Gama, T Azizah dan Betty, R Faizah. Analisis Risiko Kejadian Demam Berdarah Dengue di Desa Mojosongo Kabupaten Boyolali. Jurnal Eksplanasi. 2010; 5(2). 